\title{
Selection and evaluation of seafood-borne psychrotrophic lactic acid bacteria as inhibitors of pathogenic and spoilage bacteria
}

\author{
S. Matamoros ${ }^{a, b}$, M.F. Pilet ${ }^{a}$, F. Gigout ${ }^{b}$, H. Prévost ${ }^{a}$ and F. Leroi ${ }^{b, ~ *}$
}

\author{
a UMR INRA 1014 SECALIM ENVN-ENITIAA, ENITIAA, Nantes, France \\ ${ }^{\mathrm{b}}$ Département de Sciences et Techniques Alimentaires Marines, IFREMER, Rue de l'lle d'Yeu, BP21105, 44311 \\ Nantes Cedex 3, France \\ *: Corresponding author : F. Leroi, Tel.: +33 2403741 72, email address : Francoise.Leroi@ifremer.fr
}

\begin{abstract}
:
In this study, inhibitory psychrotrophic lactic acid bacteria were isolated and investigated for future use in biopreservation of seafood products. Screening of 5575 colonies isolated from various seafood products resulted in the selection of 132 colonies presenting inhibitory properties. Among them, 52 isolates had characteristics of $\angle A B$ and showed growth at $15^{\circ} \mathrm{C}$ but not at $30^{\circ} \mathrm{C}$. The inhibition spectrum of these 52 isolates against 14 target strains (Gram-positive and -negative) showed inhibition of typical seafood spoiling and pathogenic bacteria and enabled the formation of seven interesting clusters. Sequencing of the 16S rRNA gene of a representative isolate from each cluster identified three Leuconostoc gelidum, two Lactococcus piscium, one Lactobacillus fuchuensis and one Carnobacterium alterfunditum. Theses strains did not produce histamine nor tyramine, and showed no particular antibiotic resistance profile. Growth rate as a function of temperature was tested for one $L$. piscium and one L. gelidum isolate and confirmed their psychrotrophic behavior. One out of seven isolates showed bacteriocin-like activity. The inhibition mechanisms of the other isolates are still unknown but may be due to competition for substrate. Absence of a bacteriocin-like component could be a positive point to gain rapid authorization for food application in France. This collection of LAB is now ready for testing on products.
\end{abstract}

Keywords: Lactic acid bacteria; Seafood; Inhibition; Psychrotrophic; Lactococcus piscium; Leuconostoc gelidum; Lactobacillus fuchuensis; Carnobacterium alterfunditum 


\section{Introduction}

Biopreservation is an innovative way of extending the shelf-life of food products and reducing microbial risks. Biopreservation consists of the inoculation of food products with selected bacterial strains able to inhibit the growth of undesirable bacteria (for a review see Rodgers 2001). Lactic acid bacteria (LAB) are particularly interesting candidates for this technique. Indeed, they are frequently naturally present in food products and are often strong competitors, by producing a wide range of antimicrobial metabolites such as organic acids, hydrogen peroxide, diacetyl and bacteriocins. They are generally recognized as safe microorganisms (Adams 1999) and benefit from the healthy image of many dairy products.

Although biopreservation is currently applied in fermented food, there are few examples in non-fermented products such as seafood. Some selected microorganisms that have given good results in a model medium are not efficient in seafood because they do not grow in this low-sugar content matrix, are not adapted to a chilled temperature or spoil the product (Wessels and Huss 1996). Most of the successful studies in marine products have been obtained on the inhibition of Listeria spp. by different species of $L A B$, mainly from the Carnobacterium genus (Nilsson et al. 1999; Katla et al. 2001; Yamazaki et al. 2003; Brillet et al. 2004, 2005; Vescovo et al. 2006), which is due to either bacteriocin production (Richard et al. 2003) or competition mechanisms (Nilsson et al. 2005). However, other endogenous pathogenic bacteria, such as Vibrio parahaemolyticus, V. vulnificus and V. cholerae, Clostridium botulinum, histamine-producing bacteria, and post-contaminating bacteria, such as Staphylococcus aureus or Salmonella spp, can be associated with seafood safety and require special attention (Feldhusen 2000; Huss et al. 2000; Sumner and Ross 2002). Moreover, due to their high content of low-molecular weight nitrogenous compounds, their neutral $\mathrm{pH}$ and high water activity value, seafood products are also extremely sensitive to microbial spoilage. Shewanella putrefaciens, Photobacterium phosphoreum, Aeromonas spp. and Pseudomonas spp. are the main spoilers of fresh fish products stored in air or under vacuum or modified atmosphere packaging (MAP) (Gram and Huss 1996; Gram and Dalgaard 2002). In lightly preserved fish products ( $\mathrm{NaCl}<6 \%$ in water phase, $\mathrm{pH}>5$ ) like cold-smoked fish, other microorganisms such as LAB, Enterobacteriaceae, Brochothrix thermosphacta and Vibrio spp. can contribute to spoilage (Jorgensen et al. 2000; Leroi et al. 2001; Stohr et al. 2001; Joffraud et al. 2006). In order to develop the biopreservation technology to improve quality and extend the shelf-life of seafood, the selection of LAB that show inhibitory properties against both pathogenic and spoilage bacteria at chilled temperatures is necessary.

In this study, a large selection of seafood products was screened for the presence of LAB able to grow at $15^{\circ} \mathrm{C}$ but not at $30^{\circ} \mathrm{C}$ and to inhibit at least one out of four target strains ( $L$. monocytogenes, St. xylosus, Pseudomonas sp., Serratia liquefaciens). The selected isolates were then tested against fourteen new target strains, Gram-positive and -negative, spoiling and pathogenic bacteria, isolated from marine products. The most promising LAB were identified and their inhibition mechanisms tentatively explained. Growth profile as a function of temperature was determined to characterize their psychrotrophic behaviour. Biogenic amines production and antibiotic resistance were tested to ensure the safety of the strains for future use in biopreservation of seafood products.

\section{Materials and methods}

\subsection{First screening: isolation of inhibitory bacteria from seafood products}

Fifty-one samples of twenty-seven different commercial seafood products listed in Table 1 were obtained from different supermarkets (Nantes, France). They were stored at 4 or $8^{\circ} \mathrm{C}$ and opened for analysis between 10 days before and 10 days after the use-by date. Aliquots $(30 \mathrm{~g})$ of each product were stomached in physiological water (5-fold dilution) $\left(1 \mathrm{~g} \mathrm{I}^{-1}\right.$ tryptone 
[Biokar Diagnostics, Beauvais, France], $8.5 \mathrm{~g} \mathrm{l}^{-1} \mathrm{NaCl}$ ), four successive decimal dilutions were prepared and $0.1 \mathrm{ml}$ of the mother suspension and each dilution were spread on Elliker agar plates (four plates per dilution) (48.5 g l$~^{-1}$ Elliker [Biokar Diagnostics], $15 \mathrm{~g} \mathrm{l}^{-1}$ agar [Biokar Diagnostics]). Plates were then incubated in anaerobic conditions (Anaerocult $A$, Merck, Darmstadt, Germany) at $8^{\circ} \mathrm{C}$ for 10 to 15 days. At that time, plates presenting between 10 to 15 colonies were selected for a double-layer inhibition test.

Four target strains from the HURDLETECH collection (collection established during the Integrated Project (IP) SEAFOODplus contract No. FOOD-CT-2004-506359) stored at IFREMER (Nantes, France) were selected for the first inhibition test: L. monocytogenes (EU2160), St. xylosus (DSMZ 20029), Pseudomonas group I (EU2189) and Se. liquefaciens (EU2196). These strains were pre-cultivated $48 \mathrm{~h}$ in Brain Heart Broth $\left(37 \mathrm{~g}^{-1}\right.$ BHB, Biokar Diagnostics) as described in Table 2 before being diluted and added to molten soft BHB agar (37 $\mathrm{g} \mathrm{l}^{-1} \mathrm{BHB}, 10 \mathrm{~g} \mathrm{I}^{-1}$ agar) and then spread on an isolation plate showing growth of 10 to 15 colonies. The target strains were tested separately: one strain per plate. Plates were then incubated for $24 \mathrm{~h}$ at the specific target strain growth temperature (Table 2) in order to obtain a regular lawn. The presence of an inhibition zone was checked visually. Based on the colony appearance, approximately one out of three colonies per plate showing an inhibition zone was picked up and cultivated in Elliker broth at $15^{\circ} \mathrm{C}$. Selected isolates were isolated twice on Elliker agar plates at $15^{\circ} \mathrm{C}$, and frozen in Elliker containing $10 \% \mathrm{v} / \mathrm{v}$ glycerol (Panreac Quimicia SA, Barcelona, Spain) at $-80^{\circ} \mathrm{C}$.

\subsection{Second screening : selection of psychrotrophic lactic acid bacteria among the inhibitory isolates}

The selected isolates were cultivated at 15 and $30^{\circ} \mathrm{C}$ in Elliker broth in order to check their psychrotrophic characteristic. Growth was monitored visually by checking turbidity after $48 \mathrm{~h}$ and one week of culture. Isolates presenting growth at $15^{\circ} \mathrm{C}$ but no growth at $30^{\circ} \mathrm{C}$ after one week were selected and tested for three characteristics: Gram, catalase and oxidase tests. Only presumptive LAB i.e. Gram-positive, catalase- and oxidase-negative isolates were selected for further studies.

\subsection{Third screening: inhibitory spectrum and partial identification of the selected LAB isolates}

Investigations of the inhibitory properties of the selected isolates was enlarged to fourteen spoilage, pathogenic or surrogate target strains relevant to seafood products (listed in Table 2).

Tested LAB isolates were cultivated for $48 \mathrm{~h}$ in Elliker broth at $15^{\circ} \mathrm{C}$ before being spotted onto the surface of Elliker plates $(10 \mu \mathrm{l}$ per spot, six spots per plate) and plates were incubated anaerobically for 10 days at $8^{\circ} \mathrm{C}$. A Lactobacillus curvatus strain from the IFREMER collection (SF762) that has no inhibitory properties against the fourteen target strains was included in the experiment as a negative control. The 14 target strains were precultivated in culture medium and temperature conditions specified in Table 2 . They were then individually added to $15 \mathrm{ml}$ of the same culture medium containing $10 \mathrm{~g} \mathrm{l}^{-1}$ of molten agar. Molten soft agar was then spread onto previously spotted and incubated Elliker plates. After $24 \mathrm{~h}$ of aerobic incubation at the target strain appropriate temperature, plates were examined for evidence of inhibition. The size of the inhibition zone was recorded and a score from 0 to 4 was given as follows: 0 for no inhibition, 1, 2, 3 and 4 for an inhibition halo diameter of 1, 2, 3 and $4 \mathrm{~cm}$ respectively. 
Ward's hierarchical clustering method with squared Euclidian distance was used to separate the $52 \mathrm{LAB}$ isolates into groups according to the size of their inhibition zone for the 14 target strains (Uniwin plus, version 4.01, Sigma plus, Paris, France).

Partial identification of the isolates was based on cell morphology and lactic acid configuration using the Microzym ${ }^{\circledR}$ system (Biosentec, Toulouse, France) after $48 \mathrm{~h}$ of growth in Elliker broth at $15^{\circ} \mathrm{C}$ and $16 \mathrm{~S}-23 \mathrm{~S}$ intergenic region profile as described by Kabadjova et al. (2002).

Identification of Leuconostoc species was performed by RFLP patterns as described by Kim et al. (2003) using endonuclease BsmAI (Biolabs). DNA from Ln. gelidum DSM5578 (DSMZ, Darmstadt, Germany) and Ln. inhae DSM 15101 were used for comparison.

\subsection{Identification of 7 bioprotective lactic acid bacteria}

The sequencing of the 16S rRNA gene of seven selected biopreservative isolates was performed. After $48 \mathrm{~h}$ of culture, cells were sedimented by centrifugation, washed and resuspended in T100E buffer $\left(100 \mathrm{mmol} \mathrm{I}^{-1}\right.$ Tris-Hcl, $10 \mathrm{mmol} \mathrm{I}{ }^{-1}$ EDTA). Chromosomal DNA was prepared from the suspension using the acetate method (Weisburg et al. 1991).

The primers used for the amplification of the 16S rRNA gene were fD1 (5'AGAGTTTGATCCTGGCTCAG-3') and rD1 (5'- TAAGGAGGTGATCCAGCC-3') (Weisburg et al. 1991). The PCR amplified DNA fragments with primers fD1 and rD1 contained the complete 16S rRNA gene. PCR reactions were performed in a PTC-100 thermocycler in a total volume of $50 \mu \mathrm{l}$ containing 1X PCR buffer, $1.5 \mathrm{mmol}^{-1} \mathrm{MgCl}_{2}, 1 \mu \mathrm{g} \mathrm{ml}^{-1}$ DNA, $0.8 \mu \mathrm{mol}$ $\mathrm{I}^{-1}$ each primer, $0.2 \mathrm{mmol}^{-1}$ (each) dNTP and $2 \mathrm{U}$ Taq DNA polymerase (New England Biolabs, Hitchin, UK). Amplification consisted of a $60 \mathrm{~s}$ denaturation step at $94^{\circ} \mathrm{C}$, a $60 \mathrm{~s}$ annealing step at $56^{\circ} \mathrm{C}$ and a $60 \mathrm{~s}$ extension step at $72^{\circ} \mathrm{C}$. The first cycle was preceded by incubation for $5 \mathrm{~min}$ at $94^{\circ} \mathrm{C}$. After 35 cycles, there was a final 7 min extension at $72^{\circ} \mathrm{C}$. Negative controls containing no DNA template were included in parallel. The nucleotide sequence of the amplified 16S rRNA gene was determined with an ABI 370 automated sequencer using the Taq Dye-Deoxy TM terminator cycle sequencing method (Genome Express company, Meylan, France). Anticipated errors of PCR and sequencing reactions were avoided by sequencing both DNA strands. Sequence treatment was performed using the CAP3 Sequence Assembly Program (http://pbil.univ-lyon1.fr/cap3.php) and the invcomp program (http://www.infobiogen.fr/services/analyseq/cgi-bin/invcomp in.pl). Sequences were then compared to databases using the nucleotide-nucleotide BlastN program (http://www.ncbi.nlm.nih.gov/BLASTI, Altschul et al. 1997).

Phenotypic tests were carried out as follow: lactic acid production and configuration as described above, gas production by the modified hot tube method (Dicks and van Vuuren 1987) and polysaccharide production on Elliker Petri dishes.

\subsection{Safety characteristics: biogenic amines production and antibiotics resistance}

Histamine and tyramine production was tested for the seven selected isolates. Cultures were grown $72 \mathrm{~h}$ at $15^{\circ} \mathrm{C}$ in Maijala medium (Maijala 1993) supplemented with $2 \mathrm{~g} \mathrm{l}^{-1}$ of tyrosine or $2 \mathrm{~g} \mathrm{l}^{-1}$ of histidine. Standard solutions containing 5 to $1000 \mathrm{\mu g} \mathrm{ml}^{-1}$ of pure tyramine or histamine were prepared for calibration curves. $100 \mu \mathrm{l}$ of each culture supernatant and standard solution were dansylated as described by Eerola et al. (1993). Twenty microliters of dansylated solution were analyzed by HPLC (Waters 600E Multisolvent Delivery System and Waters 2487 Dual $\lambda$ Absorbance Detector, Waters, France) on a C18 ODS2 Equisorb column (CIL Cluzeau, France). The gradient elution was carried out as described by Connil et al. (2002). Amines were detected by u.v. absorption at $254 \mathrm{~nm}$.

The antibiotic resistance was determined using agar diffusion discs of chloramphenicol, tetracycline, erythromycin, vancomycin, kanamycin, colistin and nalidixic acid as 
recommended by the supplier (BioRad, Hercules, CA, USA). Analyses were performed in triplicate.

\subsection{Characterization of the inhibitory activity}

The inhibition mechanisms of the seven selected isolates were investigated. The isolates were grown for $48 \mathrm{~h}$ at $15^{\circ} \mathrm{C}$ in $10 \mathrm{ml}$ of Elliker broth, and culture cell-free supernatants were obtained by centrifugation (18000 $\mathrm{g}$ for $10 \mathrm{~min})$. Supernatants were then submitted to different successive treatments: heating for $10 \mathrm{~min}$ at $80^{\circ} \mathrm{C}$ (step 1); adjusting the $\mathrm{pH}$ to 6.5 with 0.1 or $1 \mathrm{~mol} \mathrm{I}^{-1} \mathrm{NaOH}$ (Merck) (step 2); addition of catalase (Merck) to a final concentration of $500 \mathrm{U} \mathrm{ml}^{-1}, 30 \mathrm{~min}$ at $25^{\circ} \mathrm{C}$ (step 3); addition of proteinase $\mathrm{K}$ (Boehringer, Mannheim, Germany) to a final concentration of $0.2 \mathrm{mg} \mathrm{ml}^{-1}$, one $\mathrm{h}$ at $37^{\circ} \mathrm{C}$ (step 4). After each step, $10 \mu \mathrm{l}$ of the supernatants was spotted onto soft agar inoculated with one $\mathrm{ml}$ of precultivated target strains (Table 2). The plates were then incubated for $24 \mathrm{~h}$ at target strain temperature (Table 2) and inhibition zones were recorded.

\subsection{Temperature growth profile}

In order to confirm the psychrotrophic behavior of the selected isolates, maximal growth rate as a function of temperature was determined in an automated optical density measurements system Bioscreen C for two isolates: EU2241 and EU2247. Experiments were performed as described by Augustin et al. (1999). Isolates were subcultured ? at $15^{\circ} \mathrm{C}$ for $24 \mathrm{~h}$ (EU2241) or $72 \mathrm{~h}(\mathrm{EU} 2247)$ and then inoculated at $5 \%(\mathrm{v} / \mathrm{v})$ in modified Elliker medium (20 g/l tryptone, 5 $\mathrm{g} / \mathrm{l}$ yeast extract, $2.5 \mathrm{~g} / \mathrm{l}$ gelatin, $7.5 \mathrm{~g} / \mathrm{l}$ lactose, $7.5 \mathrm{~g} / \mathrm{l}$ glucose, $1.5 \mathrm{~g} / \mathrm{l}$ sodium acetate, $0.5 \mathrm{~g} / \mathrm{l}$ ascorbic acid, $20 \mathrm{~g} / \mathrm{l}$ sodium chloride). Modified Elliker medium was used to prevent polysaccharide production from the Leuconostoc isolates. Moreover the salt enhanced the growth of the tested isolates. Eight half-dilutions were prepared from this dilution, and $200 \mu \mathrm{l}$ of each of the nine dilutions were placed in the wells of honeycomb sterile plate. The last well of the series was filled with $200 \mu$ of sterile medium as a negative control. The plates were placed in the Bioscreen C (Labsystem, Labsystem France SA, Les Ulis, France) and incubated at constant temperature. Incubation temperatures were $0,2,5,8,11,14,17,20$, 23, 26 and $29^{\circ} \mathrm{C}$. OD measurements at $600 \mathrm{~nm}$ were performed automatically every 20 min after a 20 s shaking and recorded by the software Research Express v1.05 (Transgalactic Ltd., Helsinki, Finland).

The maximum growth rate was calculated by a linear regression method according to the equation:

$\operatorname{Ln}\left(\mathrm{N}_{\mathrm{i}}\right)=\mathrm{k}-\mu_{\max }{ }^{*} \mathrm{DT} \mathrm{T}_{\mathrm{i}}$

With $\mathrm{N}_{\mathrm{i}}$ : initial number of cell in the well and $\mathrm{DT}_{\mathrm{i}}$ : absorbance detection time in well in midexponential phase.

All calculations were done using Matlab software (The Mathworks, Natick, MA, USA).

\section{Results and discussion}

\subsection{Isolation of potentially bioprotective bacteria from seafood products}

This study presents the first steps of the selection of inhibitory LAB strains, for a biopreservative strategy of seafood products based on growth at low temperature. A total of 132 colonies were isolated from the first double layer inhibition test. Many presumptive LAB 
colonies were obtained from MAP and smoked fish products. This is consistent with previous publications (Leroi et al. 1998; Gonzalez-Rodriguez et al. 2002). With only $15 \%$ of the analyzed samples (8 out of 51), the salmon products (fresh MAP salmon and smoked salmon) were the origin of nearly $64 \%$ of the selected isolates (85 out of 132). Cold-smoked salmon has often been found to be a good provider of LAB with antimicrobial properties. Fourteen and $41 \%$ of the isolates tested from this matrix respectively by Duffes et al. (1999) and Tomé et al. (2006) have shown anti-listerial properties. From the 132 selected isolates, $54(41 \%)$ were able to grow at $15^{\circ} \mathrm{C}$ and showed no growth at $30^{\circ} \mathrm{C}$. Fifty-two (96\%) out of the 54 psychrotrophic isolates showed typical LAB characteristics, i.e. Gram-positive, catalase-negative and oxidase-negative. The screening of commercial seafood products allowed the selection of 52 inhibitory isolates, presenting $L A B$ characteristics and unable to grow at $30^{\circ} \mathrm{C}$ or above. All the results concerning the isolation and characterization of these potentially bioprotective bacteria are presented in Table 1 . These 52 LAB isolates were added to the HURDLETECH collection under numbers EU2213 to EU2264.

\subsection{Inhibition spectrum and partial identification of the isolates}

The aim of this investigation was to differentiate the 52 LAB isolates upon their inhibitory characteristics against a wide selection of Gram-positive and Gram-negative, pathogenic and spoiling strains relevant to seafood (later referred to as target strains). Most of the target strains used during the third screening to establish the inhibitory spectrum are commonly reported in seafood products.

Clustering was done to separate the 52 isolates into clusters according to the size of their inhibition zone. The mean inhibitory spectrum of each cluster is presented in Table 3. Eight distinct clusters were formed from this analysis. All clusters contained from one to 16 isolates. Cluster 8 grouped together five isolates showing the weakest inhibitory properties, including the negative control $L b$. curvatus SF762. Isolates from this cluster where not further investigated in this study.

All the tested LAB strains showed at least weak inhibition of $L$. monocytogenes. As demonstrated in many studies, this confirms the ability of LAB strains, isolated from various food products, to inhibit L. monocytogenes (Budde et al. 2003; Brillet et al. 2005; Alvarado et al. 2005; Wilson et al. 2005; Weiss and Hammes 2006). As L. monocytogenes is commonly found in ready-to-eat foods and lightly preserved seafood products (Ben Embarek 1994; Huss et al. 2000), it is interesting for a bioprotective strain to have inhibitory properties against this particular pathogen.

The 16S-23S intergenic region profile was used for the identification of the isolates at the genus level. According to Kabadjova et al. (2002) one single amplification product is obtained with Leuconostoc, Lactococcus or Streptococcus thermophilus strains, whereas Lactobacillus or Carnobacterium strains usually give 2 or 3 amplification products. The strains from the clusters 1, 2, 3, 4 and 7 were cocci showing one single PCR product of 750 bp. Considering that strains from clusters 2 and 3 were cocci producing mainly L-lactic acid, they were assigned to the genus Lactococcus. The strains from clusters 1,4 and 7 were cocci producing mainly D-lactic acid and were identified as Leuconostoc. A RFLP analysis was conducted according to Kim et al. (2003) and allowed the identification of the 26 isolates as Leuconostoc gelidum. The strains from clusters 5,6 and 8 were rods producing L- or Dlactic acid and showing 2 or 3 amplification products for the 16S-23S intergenic region. They were identified as Lactobacillus or Carnobacterium.

\subsection{Selection and characterization of 7 representative strains from the inhibitory clusters}




\subsubsection{Identification at the specie level}

For each of the seven interesting clusters, the following isolates showing the highest inhibitory effect were chosen for further analysis: EU2213, EU2229, EU2241, EU2247, EU2255, EU2257 and EU2262 (Table 3).

Sequencing of the 16S rRNA gene and comparison with online databanks enabled a more precise identification of these isolates. Isolates EU2213, EU2247 and EU2262 (from clusters 1,4 and 7 respectively) were identified as $L n$. gelidum or $L n$. inhae, both at $99 \%$ identity. RFLP analysis allowed the separation of 2 restriction fragments of approximately 200 and 700 bp. Comparison of these results with RFLP results from Ln. gelidum and Ln. inhae (Kim et al. 2003) identified them as part of the Ln. gelidum specie. These strains were heterofermentative, produced mainly $\mathrm{D}(-)$ lactic acid isomer and had a slimy colony appearance on Elliker agar. Polysaccharide production could be a spoilage characteristic on some products. However, according to the USDA nutrient database (http://www.nal.usda.gov/fnic/foodcomp/search/) seafood products have a low sugar content so it is unlikely that polysaccharide production will be a problem. Isolates EU2229 and EU2241 (from clusters 2 and 3 respectively) were identified as Lactococcus piscium at $99 \%$ identity. They were homofermentative cocci producing mainly the $L(+)$ isomer of lactic acid. Isolate EU2255 from cluster 5 was identified as Lactobacillus fuchuensis at $98 \%$ identity and was heterofermentative. Isolate EU2257 from cluster 6 was identified as Carnobacterium alterfunditum at $98 \%$ identity and was homofermentative. The sequencing results and phenotypic characteristics of the seven selected isolates are summarized in Table 4.

Lactococcus spp. and Leuconostoc spp. have already been isolated from seafood products (Mauguin and Novel 1994; Wilderdyke et al. 2004) although, generally, Carnobacterium spp. and Lactobacillus spp. were found dominant among the LAB flora (Leroi et al. 1998; Truelstrup-Hansen et al. 1998; Gonzalez-Rodriguez et al. 2002; Rachman et al. 2004).

Although belonging to genera frequently associated with seafood products, the species identified during this study are not often isolated from seafood products. This may be due to the fact that only psychrotrophic isolates were selected during the screening.

\subsubsection{Safety aspects : Biogenic amines production and resistance to antibiotics}

Before considering their use for the biopreservation of food products, some safety aspects of the $L A B$ isolates must be investigated. Knowledge of the antibiotic resistance and sensitivity of the strains is recommended (Rodgers 2001). All of the seven tested strains were found to be sensitive to chloramphenicol, tetracycline and erythromycin except isolate EU2241 which showed intermediate resistance to erythromycin. All isolates were resistant to vancomycin, kanamycin, colistin and nalidixic acid. These resistances are widely described among LAB and are usually considered as intrinsic and non transferable (Mathur and Singh 2005).

Biogenic amines production in food is often related to the presence of bacteria, including $L A B$ (ten Brink et al. 1990). Seafood products have already been related to the presence of high amounts of biogenic amines (Leisner et al. 1994; Emborg et al. 2002) and biogenic amine production by biopreservative LAB strains have already been reported (Connil et al. 2002; Brillet et al. 2004). The histamine and tyramine production for the seven tested strains was below the detection threshold of $5 \mathrm{\mu g} \mathrm{m}^{-1}$ meaning that the isolates characterized in this study could be tested in products without risks of biogenic amine production.

\subsubsection{Inhibition mechanisms of the seven selected isolates}

Investigation of the inhibition mechanisms was carried out. For five out of seven isolates tested (EU2213, EU2229, EU2241, EU2255, EU2262), no inhibition zone was recorded when the untreated supernatant was used. The inhibition recorded in previous screenings seems to be related to the presence of the colony, maybe by strong colony-dependent 
acidification or nutritional competition. Tests on products will be carried out to ensure that there is no downshift of the sensorial quality induced by these isolates. The culture supernatant of isolate EU2257 showed activity when spotted against $L b$. farciminis, $B x$. thermosphacta, Sw. putrefaciens, L. monocytogenes, St. xylosus, Pseudomonas sp, Se. liquefaciens and St. aureus. Heating stopped the activity, i. e. no activity was detected for spots of step 1, 2, 3 and 4 . A thermo sensitive compound may be responsible for this inhibition. More investigation are needed to determine the exact nature of this compound. The culture supernatant of isolate EU2247 identified as a Ln. gelidum showed activity against $L b$. farciminis and $L$. monocytogenes. This inhibition did not disappear after heat treatment, $\mathrm{pH}$ adjustment and catalase treatment. Addition of proteinase $\mathrm{K}$ stopped the activity, suggesting that this isolate produced a bacteriocin-like component. Bacteriocin-like components have already been identified from Leuconostoc spp. (Daba et al. 1991; Hastings et al. 1991; Budde et al. 2003). The inhibition spectrum of this type of component is generally restricted to Listeria spp. and closely related Gram-positive strains (Jack et al. 1996; Helander et al. 1997; Millette et al. 2004) and it was also noticed in this study.

\subsection{Study of the psychrotrophic behavior of Leuconostoc gelidum EU2247 and Lactococcus piscium EU2241}

Different strategies for the biopreservation of seafood products have already been conducted (Brillet et al. 2004; Altieri et al. 2005) but none of them focused on the cold adaptation of protective strains. Lactococcus or Leuconostoc species are not usually described as pychrotrophic lactic acid bacteria. For that reason, the growth rate as a function of temperature was tested for two isolates: Lc. piscium EU2241 and Ln. gelidum EU2247. According to optical density measurements, optimum growth temperature of isolate EU2241 was $26^{\circ} \mathrm{C}$ with a maximal growth rate of: $\mu_{\max 26}=0.5921 \mathrm{~h}^{-1}\left(\mathrm{~T}_{\mathrm{g} 26}=1 \mathrm{~h} 11 \mathrm{~min}\right)$. Growth was recorded at $0^{\circ} \mathrm{C}$, with a maximal growth rate of: $\mu_{\max 0}=0.0243 \mathrm{~h}^{-1}\left(\mathrm{~T}_{\mathrm{g} 0}=28 \mathrm{~h} 31 \mathrm{~min}\right)$. The optimum growth temperature of isolate EU2247 was $20^{\circ} \mathrm{C}$, with a maximal growth rate of $\mu_{\max 20}=0.4399 \mathrm{~h}^{-1}\left(\mathrm{~T}_{\mathrm{g} 20}=1 \mathrm{~h} 34 \mathrm{~min}\right)$. Growth was also recorded at $0^{\circ} \mathrm{C}$, with a maximal growth rate $\mu_{\max 0}=0.0278 \mathrm{~h}^{-1}\left(\mathrm{~T}_{\mathrm{g}}=24 \mathrm{~h} 56 \mathrm{~min}\right)$. No growth was recorded at $29^{\circ} \mathrm{C}$ or above. Maximal growth rate as a function of temperature is presented in Fig. 1.

LAB are generally mesophilic organisms, with an optimal growth temperature around $30^{\circ} \mathrm{C}$ and a maximum between 35 and $45^{\circ} \mathrm{C}$. Some LAB have been described as psychrotrophic organisms which means that they are capable of growing at $0^{\circ} \mathrm{C}$ (van de Guchte et al. 2002). The isolates presented in this study grow well at low temperature and have a maximum growth temperature below $30^{\circ} \mathrm{C}$, which is very uncommon among psychtrophic LAB. In fact, only one LAB isolated from vacuum-packed refrigerated beef and presenting the same characteristic has been identified, Lb. algidus (Kato et al. 2000). The interest of selecting bioprotective $L A B$ isolates possessing this characteristic is that they will have an inhibitory effect at chilled storage temperature, making them more competitive against the spoiling flora which generally develops at this temperature. They will not grow at the body temperature (meaning that no growth will occur in the human digestive system). Moreover they will not grow in the conditions used to enumerate total mesophilic bacteria (PCA, $30^{\circ} \mathrm{C}$ ), a count used by many industries as an hygienic criterion, i.e. inoculation with these bioprotective strains will not mask any hygienic problem. Their growth characteristics make them very promising for the biopreservation of refrigerated food products.

\section{Conclusions and future work}

The creation of a collection of lactic acid bacteria strains from seafood products has been successfully carried out. All these 52 isolates share similar characteristics: inhibition of 
spoiling and pathogenic/surrogate bacteria and psychrotrophic characteristics with absence of growth at $30^{\circ} \mathrm{C}$. The identification of seven representative isolates revealed different genera and species such as $L n$. gelidum, $L c$. piscium, $L b$. fuchuensis and Cb. alterfunditum. To our knowledge, no work has been conducted on their potential application as bioprotective agents of those species in seafood products. Most of the tested strains do not produce bacteriocins, which can be an advantage in obtaining authorization for use for a human food application. In France (and in Europe), there is no regulation concerning the use of new strains in food; the authorization is delivered case by case by the veterinary or the fraud services (DSV- Direction des Services Vétérinaires or DGCCRF-Direction Générale de la Concurrence, de la Consommation et de la Répression des Fraudes), based on clear identification of the strains and proof of their efficacy and safety following recommendations from AFSSA (AFSSA 2002). The production of bacteriocin often implies extensive work on presumptive resistance mechanisms before the legal authorizations can be obtained. In this study, potentially bioprotective but non-bacteriocin producing LAB strains were investigated. This way, if these strains are to be used at industrial scale, authorization will be easier to obtain. Inhibitory isolates from group 5 or 7 , identified as Lb. fuchuensis and Ln. gelidum respectively, seems to be particularly interesting as they inhibit most of the pathogenic/surrogate and spoiling strains tested. However, more work is needed to investigate their in situ antimicrobial activity, as well as their safety and sensory acceptability for a food application. A combination of different bioprotective LAB could also be a strategy to improve the quality and safety of seafood products. Finally, their growth characteristics as a function of temperature is rather uncommon and make them very promising for the biopreservation of chilled seafood products.

\section{Acknowledgements}

The authors would like to thank Ms Robins for her constructive reading of the manuscript. This work was supported by grants from the EU commission under the Integrated Project (IP) SEAFOODplus contract No. FOOD-CT-2004-506359.

\section{References}

Adams, M. R., 1999. Safety of industrial lactic acid bacteria. J. Biotechnol. 68, 171-178.

AFSSA, 2002. Recommandations pour la présentation des données permettant l'évaluation de l'innocuité des micro-organismes utilisés dans le secteur agro-alimentaire - souches nouvelles ou modifiées - applications différentes de souches déjà utilisées.

Altieri, C., Speranza, B., Del Nobile, M. A. and Sinigaglia, M., 2005. Suitability of bifidobacteria and thymol as biopreservatives in extending the shelf life of fresh packed plaice fillets. J. Appl. Microbiol. 99, 1294-1302.

Altschul, S. F., Madden, T. L., Schaffer, A. A., Zhang, J., Zhang, Z., Miller, W. and Lipman, D. J., 1997. Gapped BLAST and PSI-BLAST: a new generation of protein database search programs. Nucleic Acids Res. 25, 3389-3402.

Alvarado, C., Garcia-Almendarez, B. E., Martin, S. E. and Regalado, C., 2005. Anti-Listeria monocytogenes bacteriocin-like inhibitory substances from Enterococcus faecium UQ31 isolated from artisan Mexican-style cheese. Curr. Microbiol. 51, 110-115.

Augustin, J. C., Rosso L., and Carlier V., 1999. Estimation of temperature dependent growth rate and lag time of Listeria monocytogenes by optical density measurements. J. Microbiol. Methods 38, 137-146.

Ben Embarek, P. K., 1994. Presence, detection and growth of Listeria monocytogenes in seafoods: a review. Int. J. Food Microbiol. 23, 17-34. 
Brillet, A., Pilet, M. F., Prevost, H., Bouttefroy, A. and Leroi, F., 2004. Biodiversity of Listeria monocytogenes sensitivity to bacteriocin-producing Carnobacterium strains and application in sterile cold-smoked salmon. J. Appl. Microbiol. 97, 1029-1037.

Brillet, A., Pilet, M. F., Prevost, H., Cardinal, M. and Leroi, F., 2005. Effect of inoculation of Carnobacterium divergens V41, a bio-preservative strain against Listeria monocytogenes risk, on the microbiological, chemical and sensory quality of cold-smoked salmon. Int. J. Food Microbiol. 104, 309-324.

Budde, B. B., Hornbaek, T., Jacobsen, T., Barkholt, V. and Koch, A. G., 2003. Leuconostoc carnosum 4010 has the potential for use as a protective culture for vacuum-packed meats: culture isolation, bacteriocin identification, and meat application experiments. Int. J. Food Microbiol. 83, 171-184.

Connil, N., Plissoneau L., Onno B., Pilet M. F., Prevost H., and Dousset X., 2002. Growth of Carnobacterium divergens V41 and production of biogenic amines and divercin V41 in sterile cold-smoked salmon extract at varying temperatures, $\mathrm{NaCl}$ levels, and glucose concentrations. J. Food Prot. 65, 333-338.

Daba, H., Pandian, S., Gosselin, J. F., Simard, R. E., Huang, J. and Lacroix, C., 1991. Detection and activity of a bacteriocin produced by Leuconostoc mesenteroides. Appl. Environ. Microbiol. 57, 3450-3455.

Dicks, L. M. T. and van Vuuren, H. J. J., 1987. A modification of the hot-tube method for the detection of carbon dioxide produced by heterofermentative Lactobacillus strains. J. Microbiol. Methods 6, 273-275.

Duffes, F., Leroi, F., Boyaval, P. and Dousset, X., 1999. Inhibition of Listeria monocytogenes by Carnobacterium spp. strains in a simulated cold smoked fish system stored at $4^{\circ} \mathrm{C}$. Int. J. Food Microbiol. 47, 33-42.

Eerola, S., Hinkkanen R., Lindfors E., and Hirvi T., 1993. Liquid chromatographic determination of biogenic amines in dry sausages. J. AOAC Int. 76, 575-577.

Emborg, J., Laursen B. G., Rathjen T., and Dalgaard P., 2002. Microbial spoilage and formation of biogenic amines in fresh and thawed modified atmosphere-packed salmon (Salmo salar) at $2^{\circ} \mathrm{C}$. J. Appl. Microbiol. 92, 790-799.

Feldhusen, F., 2000. The role of seafood in bacterial foodborne diseases. Microb. Infect. 2, 1651-1660.

Gonzalez-Rodriguez, M. N., Sanz, J. J., Santos, J. A., Otero, A. and Garcia-Lopez, M. L., 2002. Numbers and types of microorganisms in vacuum-packed cold-smoked freshwater fish at the retail level. Int. J. Food Microbiol. 77, 161-168.

Gram, L. and Dalgaard, P., 2002. Fish spoilage bacteria--problems and solutions. Curr. Opin. Biotechnol. 13, 262-266.

Gram, L. and Huss, H. H., 1996. Microbiological spoilage of fish and fish products. Int. J. Food Microbiol. 33, 121-137.

Hastings, J. W., Sailer, M., Johnson, K., Roy, K. L., Vederas, J. C. and Stiles, M. E., 1991. Characterization of leucocin A-UAL 187 and cloning of the bacteriocin gene from Leuconostoc gelidum. J. Bacteriol. 173, 7491-7500.

Helander, I. M., von Wright, A. and Mattila-Sandholm, T.-M., 1997. Potential of lactic acid bacteria and novel antimicrobials against Gram-negative bacteria. Trends Food Sci. Tech. 8, 146-150.

Huss, H. H., Reilly, A. and Ben Embarek, P. K., 2000. Prevention and control of hazards in seafood. Food Control 11, 149-156.

Jack, R. W., Wan, J., Gordon, J., Harmark, K., Davidson, B. E., Hillier, A. J., Wettenhall, R. E., Hickey, M. W. and Coventry, M. J., 1996. Characterization of the chemical and antimicrobial properties of piscicolin 126, a bacteriocin produced by Carnobacterium piscicola JG126. Appl. Environ. Microbiol. 62, 2897-2903.

Joffraud, J. J., Cardinal, M., Cornet, J., Chasles, J. S., Léon, S., Gigout, F. and Leroi, F., 2006. Effect of bacterial interactions on the spoilage of cold-smoked salmon. Int. J. Food Microbiol. 112, 51-61. 
Jorgensen, L. V., Dalgaard, P. and Huss, H. H., 2000. Multiple compound quality index for cold-smoked salmon (Salmo salar) developed by multivariate regression of biogenic amines and $\mathrm{pH}$. J. Agri. Food Chem. 48, 2448-2453.

Kabadjova, P., Dousset, X., Le Cam, V. and Prevost, H., 2002. Differentiation of closely related Carnobacterium food isolates based on 16S-23S ribosomal DNA intergenic spacer region polymorphism. Appl. Environ. Microbiol. 68, 5358-5366.

Katla, T., Moretro, T., Aasen, I. M., Holck, A., Axelsson, L. and Naterstad, K., 2001. Inhibition of Listeria monocytogenes in cold smoked salmon by addition of sakacin $\mathrm{P}$ and/or live Lactobacillus sakei cultures. Food Microbiol. 18, 431-439.

Kato, Y., R. Sakala M., Hayashidani H., Kiuchi A., Kaneuchi C., and Ogawa M., 2000. Lactobacillus algidus sp. nov., a psychrophilic lactic acid bacterium isolated from vacuumpackaged refrigerated beef. Int. J. Syst. Evol. Microbiol. 50, 1143-1149.

Kim, B., Lee, J., Jang, J., Kim, J. and Han, H., 2003. Leuconostoc inhae sp. nov., a lactic acid bacterium isolated from kimchi. Int. J. Syst. Evol. Microbiol. 53, 1123-1126.

Leisner, J. J., Millan J. C., Huss H. H., and Larsen L. M., 1994. Production of histamine and tyramine by lactic acid bacteria isolated from vacuum-packed sugar-salted fish. J. Appl. Bacteriol. 76, 417-423.

Leroi, F., Joffraud, J. J., Chevalier, F. and Cardinal, M., 1998. Study of the microbial ecology of cold-smoked salmon during storage at $8^{\circ} \mathrm{C}$. Int. J. Food Microbiol. 39, 111-121.

Leroi, F., Joffraud, J. J., Chevalier, F. and Cardinal, M., 2001. Research of quality indices for cold-smoked salmon using a stepwise multiple regression of microbiological counts and physico-chemical parameters. J. Appl. Microbiol. 90, 578-587.

Maijala, R. L., 1993. Formation of histamine and tyramine by some lactic acid bacteria in MRS-broth and modified decarboxylation agar. Lett. Appl. Microbiol. 17, 40-43.

Mauguin, S. and Novel, G., 1994. Characterization of lactic acid bacteria isolated from seafood. J. Appl. Bacteriol. 76, 616-625.

Mathur, S., and Singh R., 2005. Antibiotic resistance in food lactic acid bacteria--a review. Int. J. Food Microbiol. 105, 281-295.

Millette, M., Smoragiewicz, W. and Lacroix, M., 2004. Antimicrobial potential of immobilized Lactococcus lactis subsp. lactis ATCC 11454 against selected bacteria. J. Food Prot. 67, 1184-1189.

Nilsson, L., Gram, L. and Huss, H. H., 1999. Growth control of Listeria monocytogenes on cold-smoked salmon using a competitive lactic acid bacteria flora. J. Food Prot. 62, 336-342.

Nilsson, L., Hansen, T. B., Garrido, P., Buchrieser, C., Glaser, P., Knochel, S., Gram, L. and Gravesen, A., 2005. Growth inhibition of Listeria monocytogenes by a nonbacteriocinogenic Carnobacterium piscicola. J. Appl. Microbiol. 98, 172-183.

Rachman, C., Fourrier, A., Sy, A., De La Cochetiere, M. F., Prevost, H. and Dousset, X., 2004. Monitoring of bacterial evolution and molecular identification of lactic acid bacteria in smoked salmon during storage. Lait, 145-154.

Richard, C., Brillet, A., Pilet, M. F., Prevost, H. and Drider, D., 2003. Evidence on inhibition of Listeria monocytogenes by divercin V41 action. Lett. Appl. Microbiol. 36, 288-292.

Rodgers, S., 2001. Preserving non-fermented refrigerated foods with microbial cultures - a review. Trends in Food Science \& Technology 12, 276-284.

Stohr, V., Joffraud, J. J., Cardinal, M. and Leroi, F., 2001. Spoilage potential and sensory profile associated with bacteria isolated from cold-smoked salmon. Food Res. Int. 34, 797806.

Sumner, J. and Ross, T., 2002. A semi-quantitative seafood safety risk assessment. Int. J. Food Microbiol. 77, 55-59.

ten Brink, B., Damink C., Joosten H. M., and Huis in 't Veld J. H., 1990. Occurrence and formation of biologically active amines in food. Int. J. Food Microbiol. 11, 73-84.

Tomé, E., Teixeira, P. and Gibbs, P. A., 2006. Anti-listerial inhibitory lactic acid bacteria isolated from commercial cold smoked salmon. Food Microbiol. 23, 399-405.

Truelstrup-Hansen, L., Rontved, S. D. and Huss, H. H., 1998. Microbiological quality and shelf life of cold-smoked salmon from three different processing plants. Food Microbiol. 15, 137-150. 
van de Guchte, M., Serror P., Chervaux C., Smokvina T., Ehrlich S. D., and Maguin E., 2002. Stress responses in lactic acid bacteria. Antonie Van Leeuwenhoek 82, 187-216.

Vescovo, M., Gianluigi, S. and Zacconi, C., 2006. Inhibition of Listeria innocua growth by antimicrobial-producing lactic acid cultures in vacuum-packed cold-smoked salmon. Food Microbiol. 23, 689-693.

Weisburg, W. G., Barns, S. M., Pelletier, D. A. and Lane, D. J., 1991. 16S ribosomal DNA amplification for phylogenetic study. J. Bacteriol. 173, 697-703.

Weiss, A. and Hammes, W. P., 2006. Lactic acid bacteria as protective cultures against Listeria spp. on cold smoked salmon. Eur. Food Res. Technol. 222, 343-346.

Wessels, S. and Huss, H. H., 1996. Suitability of Lactococcus lactis subsp lactis ATCC 11454 as a protective culture for lightly preserved fish products. Food Microbiol. 13, 323-332.

Wilderdyke, M. R., Smith, D. A. and Brashears, M. M., 2004. Isolation, identification, and selection of lactic acid bacteria from alfalfa sprouts for competitive inhibition of foodborne pathogens. J. Food Prot. 67, 947-951.

Wilson, A. R., Sigee, D. and Epton, H. A., 2005. Anti-bacterial activity of Lactobacillus plantarum strain SK1 against Listeria monocytogenes is due to lactic acid production. J. Appl. Microbiol. 99, 1516-1522.

\section{Tables}

Yamazaki, K., Suzuki, M., Kawai, Y., Inoue, N. and Montville, T. J., 2003. Inhibition of Listeria monocytogenes in cold-smoked salmon by Carnobacterium piscicola CS526 isolated from frozen surimi. J. Food Prot. 66, 1420-1425. 
Table 1: Number of colonies screened and selected per product

*: MAP : modified atmosphere packaging

$\dagger$ : number of colonies showing inhibition of at least one target strain among Listeria monocytogenes (EU2160), Staphylococcus xylosus (DSMZ 20029), Pseudomonas group I (EU2189) and Serratia liquefaciens (EU2196). In bracket, percentage of colonies showing an inhibition

\begin{tabular}{|c|c|c|c|c|c|}
\hline Product name & $\begin{array}{l}\text { Colonies } \\
\text { covered }\end{array}$ & $\begin{array}{l}\text { Colonies } \\
\text { showing } \\
\text { inhibition† (\%) }\end{array}$ & $\begin{array}{l}\text { Isolated } \\
\text { colonies }\end{array}$ & $\begin{array}{l}\text { Selected } \\
\text { isolates } \\
\text { based on } \\
\text { growth } \\
\text { temperature }\end{array}$ & $\begin{array}{l}\text { Selected } \\
\text { isolates based } \\
\text { on r LAB } \\
\text { characteristics§ }\end{array}$ \\
\hline MAP* salmon & 718 & $151(21 \%)$ & 48 & 39 & 39 \\
\hline MAP* sea-bream & 240 & $11(4 \%)$ & 13 & 7 & 5 \\
\hline Cold-smoked salmon & 554 & $221(40 \%)$ & 37 & 5 & 5 \\
\hline $\begin{array}{l}\text { MAP* rough head } \\
\text { grenadier }\end{array}$ & 520 & $24(4 \%)$ & 7 & 3 & 3 \\
\hline MAP* shrimp & 157 & $26(16 \%)$ & 11 & 0 & 0 \\
\hline Smoked haddock & 217 & $4(2 \%)$ & 4 & 0 & 0 \\
\hline Roe cod (tarama) & 174 & $0(0 \%)$ & 4 & 0 & 0 \\
\hline $\mathrm{MAP}^{*}$ whiting & 456 & $14(3 \%)$ & 3 & 0 & 0 \\
\hline Smoked herring & 300 & $2(1 \%)$ & 2 & 0 & 0 \\
\hline Smoked shark & 476 & $2(0.5 \%)$ & 2 & 0 & 0 \\
\hline Sea-bream viscera & 184 & $1(0.5 \%)$ & 1 & 0 & 0 \\
\hline Red mullet viscera & 371 & $0(0 \%)$ & 0 & 0 & 0 \\
\hline Smoked tuna fish & 368 & $0(0 \%)$ & 0 & 0 & 0 \\
\hline Smoked trout & 354 & $0(0 \%)$ & 0 & 0 & 0 \\
\hline Mackerel viscera & 198 & $0(0 \%)$ & 0 & 0 & 0 \\
\hline Salmon carpaccio & 128 & $0(0 \%)$ & 0 & 0 & 0 \\
\hline Smoked mackerel & 121 & $0(0 \%)$ & 0 & 0 & 0 \\
\hline Herring viscera & 39 & $0(0 \%)$ & 0 & 0 & 0 \\
\hline $\begin{array}{l}\text { Salted cod, shrimp } \\
\text { (fresh), roe lumpfish, roe }\end{array}$ & & & & & \\
\hline $\begin{array}{l}\text { salmon, marinated } \\
\text { sardines, anchovy, } \\
\text { mussel, pickled shell } \\
\text { fish, pickled herring }\end{array}$ & 0 & $0(0 \%)$ & 0 & 0 & 0 \\
\hline Total & 5575 & $456(8 \%)$ & 132 & 54 & 52 \\
\hline
\end{tabular}

‡: isolates able to grow at $15^{\circ} \mathrm{C}$ but not at $30^{\circ} \mathrm{C}$

§: Gram-positive, catalase- and oxidase-negative isolates, able to grow at $15^{\circ} \mathrm{C}$ but not at $30^{\circ} \mathrm{C}$ 
Table 2: Target strains, culture medium and growth temperature for two successive precultures (72 and $24 \mathrm{~h}$ ) for double-layer realization

\begin{tabular}{llll}
\hline Species & Code $^{\star}$ & Medium $\dagger$ & Temperature \\
\hline Bacillus subtilis & DSMZ10 & BHB & $37^{\circ} \mathrm{C}$ \\
Brochothrix thermosphacta & EU2206 & BHB & $20^{\circ} \mathrm{C}$ \\
Clostridium sporogenes & ENITIAA & RCM & $37^{\circ} \mathrm{C}$ \\
Escherichia coli & CIP76.24 & BHB & $37^{\circ} \mathrm{C}$ \\
Lactobacillus farciminis & EU2204 & BHB & $20^{\circ} \mathrm{C}$ \\
Listeria monocytogenes & EU2160 & BHB & $20^{\circ} \mathrm{C}$ \\
Photobacterium & EU2183 & BHB $+15 \mathrm{~g} \mathrm{I}^{-1} \mathrm{NaCl} \quad 15^{\circ} \mathrm{C}$ \\
phosphoreum & & & \\
Pseudomonas group I & EU2189 & BHB & $20^{\circ} \mathrm{C}$ \\
Psychrobacter spp. & CCUG 42949 & BHB & $20^{\circ} \mathrm{C}$ \\
Salmonella enterica & CIP81.3 & BHB & $37^{\circ} \mathrm{C}$ \\
Serratia liquefaciens & EU2196 & BHB & $20^{\circ} \mathrm{C}$ \\
Shewanella putrefaciens & EU2187 & BHB & $20^{\circ} \mathrm{C}$ \\
Staphylococcus aureus & CIP76.25 & BHB & $37^{\circ} \mathrm{C}$ \\
Staphylococcus xylosus & DSMZ 20029 & BHB & $37^{\circ} \mathrm{C}$ \\
\hline
\end{tabular}

*: CCUG: Culture Collection, University of Göteborg, Sweden; EU: HURDLETECH collection established during the European SEAFOODplus project, stored at IFREMER, Nantes, France; DSMZ: Deutsche Sammlung von Mikroorganismen und Zellkulturen $\mathrm{GmbH}$, Braunschweig, Germany; CIP: Collection de I'Institut Pasteur, Paris, France; ENITIAA: collection from ENITIAA, Nantes, France.

†: BHB: Brain Heart Broth (Biokar Diagnostics, Beauvais, France); RCM medium (Reinforced Clostridium medium, prepared according to Oxoid recommendations): $3 \mathrm{~g} \mathrm{l}^{-1}$ yeast extract (Biokar Diagnostics), $10 \mathrm{~g} \mathrm{I}^{-1}$ meat extract (Oxoid LTD., Basingstoke, Hampshire, England), $10 \mathrm{~g} \mathrm{l}^{-1}$ peptone (Oxoid LTD.), $5 \mathrm{~g} \mathrm{l}^{-1}$ glucose (Merck), $1 \mathrm{~g} \mathrm{l}^{-1}$ potato starch (La Bovida, Nanterre, France), $5 \mathrm{~g} \mathrm{l}^{-1} \mathrm{NaCl}$ (Merck), $3 \mathrm{~g} \mathrm{l}^{-1}$ sodium acetate (Merck), $0.5 \mathrm{~g} \mathrm{l}^{-1}$ cysteine hydrochloride (Sigma-Aldrich, St Quentin Fallavier, France), $0.5 \mathrm{~g} \mathrm{I}^{-1}$ agar (Biokar Diagnostics). The $\mathrm{pH}$ was adjusted at 6.9 before autoclaving.

Table 3: Mean inhibitory spectrum of eight clusters of psychrotrophic LAB against fourteen target strains (the number represent the mean inhibition halo diameter of the group, in $\mathrm{cm}$ ). Groups are obtained by the Ward's hierarchichal clustering method.

\begin{tabular}{|c|c|c|c|c|c|c|c|c|c|c|c|c|c|c|c|}
\hline & & Tars & t str & & & & & & & & & & & & \\
\hline & & Gra & $n+$ & & & & & & Grar & $n-$ & & & & & \\
\hline$\frac{\frac{k}{\bar{d}}}{\frac{\omega}{\omega}}$ & 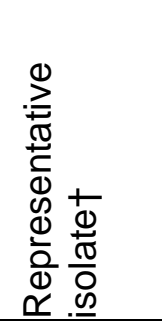 & 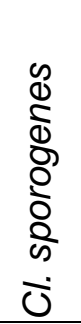 & 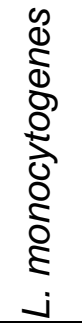 & 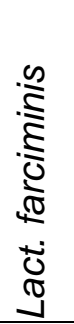 & 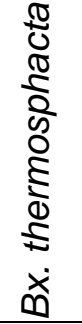 & 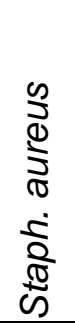 & 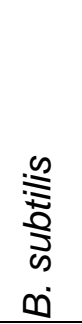 & 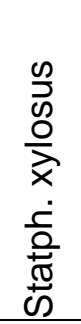 & 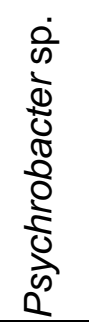 & 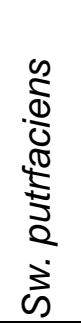 & 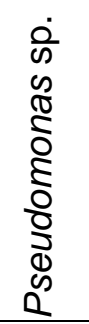 & 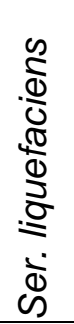 & $\begin{array}{l}\frac{1}{5} \\
d \\
\frac{d}{2} \\
\frac{2}{2} \\
0 \\
0 \\
\frac{1}{2} \\
\frac{1}{2}\end{array}$ & 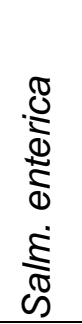 & $\begin{array}{l}\bar{\delta} \\
\text { ய }\end{array}$ \\
\hline $1(16)$ & EU2213 & 4.0 & 1.0 & 0.0 & 0.0 & 0.0 & 0.0 & 0.0 & 0.0 & 0.0 & 2.2 & 2.0 & 0.0 & 0.0 & 0.0 \\
\hline $2(12)$ & EU2229 & 4.0 & 2.0 & 1.0 & 1.0 & 1.0 & 0.0 & 0.0 & 1.3 & 1.0 & 3.0 & 2.0 & 1.0 & 0.0 & 0.0 \\
\hline $3(6)$ & EU2241 & 4.0 & 2.0 & 1.0 & 2.0 & 1.0 & 0.0 & 0.0 & 4.0 & 4.0 & 2.0 & 2.0 & 3.0 & 1.0 & 0.0 \\
\hline
\end{tabular}



4 (9) EU2247 $4 \begin{array}{llllllllllllll}4.0 & 1.7 & 3.0 & 1.0 & 0.0 & 0.0 & 0.0 & 4.0 & 4.0 & 2.0 & 2.0 & 0.0 & 0.0 & 0.0\end{array}$
$\begin{array}{llllllllllllllll}5 \text { (2) } & \text { EU2255 } & 3.0 & 2.0 & 1.0 & 1.0 & 1.0 & 1.0 & 0.0 & 2.0 & 2.0 & 2.0 & 2.0 & 2.0 & 1.0 & 1.0\end{array}$

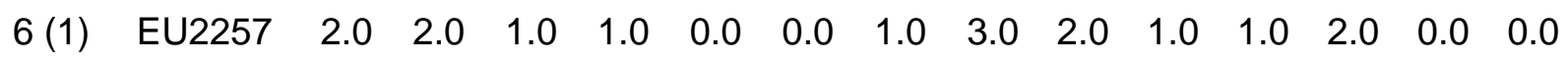

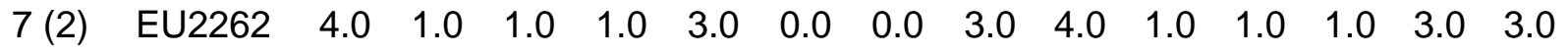
$\begin{array}{llllllllllllllll}8(4) & \text { N/A } & 0.0 & 1.0 & 0.8 & 0.0 & 0.0 & 0.0 & 0.0 & 1.0 & 0.4 & 0.2 & 0.2 & 0.2 & 0.0 & 0.0\end{array}$

*: in brackets : number of isolates per cluster.

$\dagger$ : name of the selected representative isolate in the HURDLTECH collection

Table 4: Phenotypic and molecular characteristics of the seven representative LAB isolates

\begin{tabular}{|c|c|c|c|c|c|c|}
\hline $\begin{array}{l}\bar{d} \\
\bar{n} \\
\bar{U} \\
\end{array}$ & 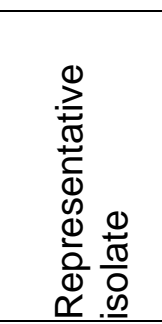 & $\begin{array}{l}\frac{\tilde{0}}{2} \\
\frac{0}{0} \\
\stackrel{0}{0}\end{array}$ & 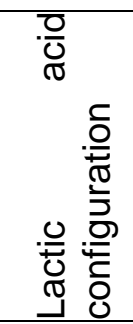 & 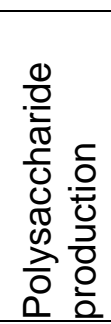 & 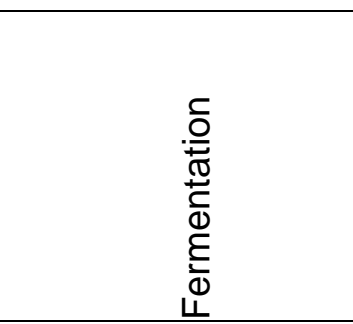 & 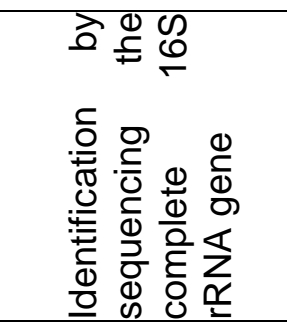 \\
\hline 1 & EU2213 & MAP salmon & $\mathrm{D}(-)$ & Yes & Hetero-fermentation & $\begin{array}{l}\text { Leuconostoc } \\
\text { inhae/gelidum }\end{array}$ \\
\hline 2 & EU2229 & MAP salmon & $\mathrm{L}(+)$ & No & Homo-fermentation & $\begin{array}{l}\text { Lactococcus } \\
\text { piscium }\end{array}$ \\
\hline 3 & EU2241 & MAP salmon & $\mathrm{L}(+)$ & No & Homo-fermentation & $\begin{array}{l}\text { Lactococcus } \\
\text { piscium }\end{array}$ \\
\hline 4 & EU2247 & MAP salmon & $\mathrm{D}(-)$ & Yes & Hetero-fermentation & $\begin{array}{l}\text { Leuconostoc } \\
\text { inhae/gelidum }\end{array}$ \\
\hline 5 & EU2255 & MAP sea-bream & $\mathrm{L}(+)$ & No & Hetero-fermentation & $\begin{array}{l}\text { Lactobacillus } \\
\text { fuchuensis }\end{array}$ \\
\hline 6 & EU2257 & $\begin{array}{l}\text { MAP rough-head } \\
\text { grenadier }\end{array}$ & $\mathrm{L}(+)$ & No & Homo-fermentation & $\begin{array}{l}\text { Carnobacterium } \\
\text { alterfunditum }\end{array}$ \\
\hline 7 & EU2262 & $\begin{array}{l}\text { cold smoked } \\
\text { salmon }\end{array}$ & $\mathrm{D}(-)$ & Yes & Hetero-fermentation & $\begin{array}{l}\text { Leuconostoc } \\
\text { inhae/gelidum }\end{array}$ \\
\hline
\end{tabular}




\section{Figures}

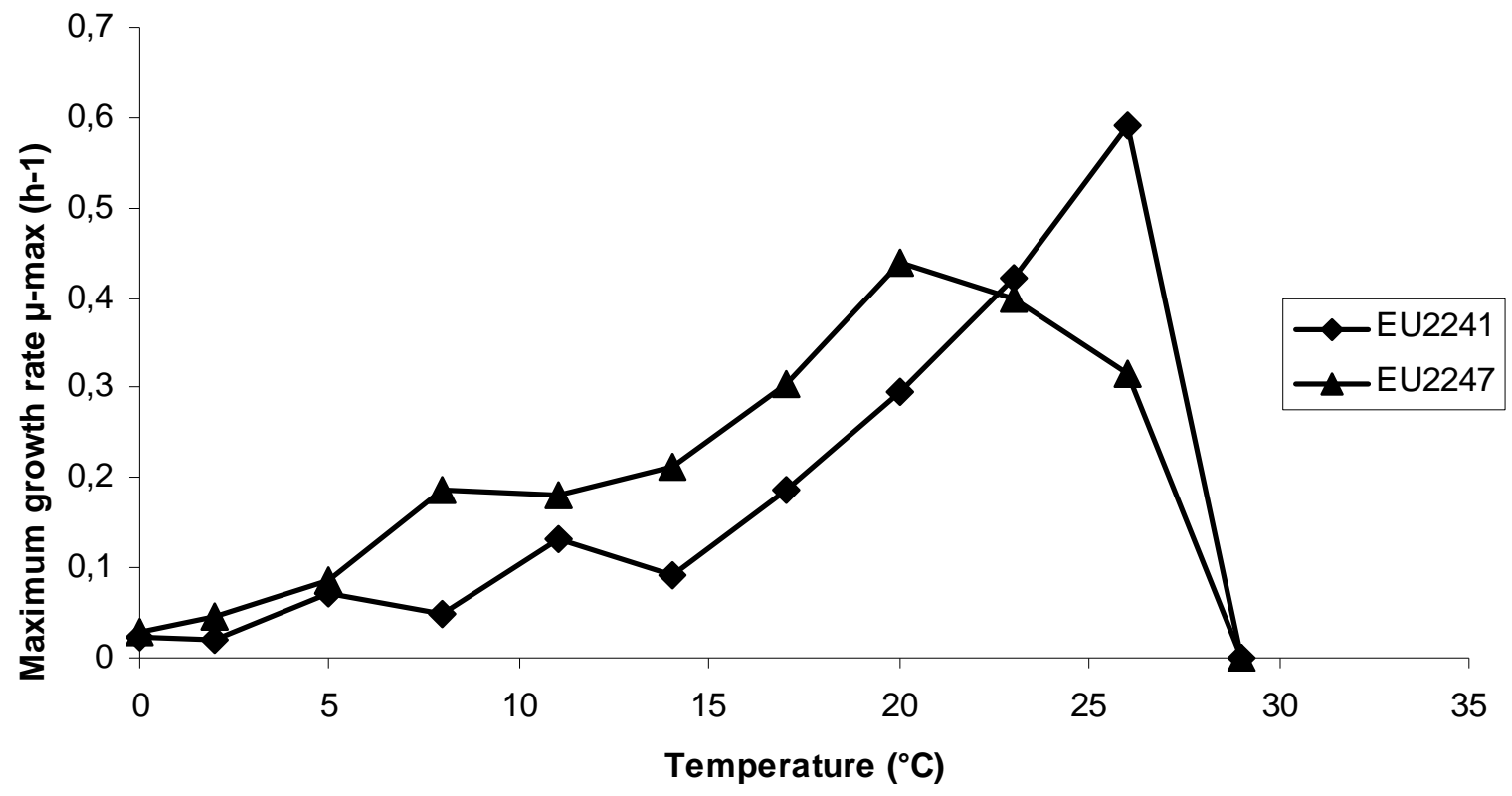

Figure 1: Maximum growth rate $\mu$ max as a function of temperature for two LAB isolates, Lactococus piscium EU2241 ( $\bullet$ ) and Leuconostoc gelidum EU2247 ( $\mathbf{A}$ ). 